\title{
The Verdesca landslide in the Agri Valley (Basilicata, southern Italy): a new geological and geomorphological framework
}

\author{
E. Gueguen ${ }^{1}$, M. Bentivenga ${ }^{2}$, R. Colaiacovo ${ }^{1}$, S. Margiotta ${ }^{1}$, V. Summa ${ }^{1}$, and I. Adurno ${ }^{a}, \uparrow$ \\ ${ }^{1}$ Institute of Methodologies for Environmental Analysis, Italian National Council for Research, Tito Scalo (PZ), Italy \\ ${ }^{2}$ Department Of Sciences, University of Basilicata, Potenza, Italy \\ ${ }^{\text {a }}$ formerly at: Institute of Methodologies for Environmental Analysis, Italian National Council for Research, \\ Tito Scalo (PZ), Italy \\ $\dagger$ deceased \\ Correspondence to: E. Gueguen (erwan.gueguen@imaa.cnr.it)
}

Received: 21 June 2014 - Published in Nat. Hazards Earth Syst. Sci. Discuss.: 24 March 2015

Accepted: 1 November 2015 - Published: 30 November 2015

\begin{abstract}
A landslide, to the west of Montemurro (a small village in southern Italy), has recently caused damage to buildings and other infrastructure in an urbanized area; as a result the development of new economic activities has been prohibited. The landslide phenomenon started in the last century and has been studied since the 1990s using classical geotechnical methods; however the sliding body continues to move. This paper presents the results of a study carried out using field surveys, geognostic investigations and TDR (time domain reflectometry) measurements in order to reconstruct the stratigraphy of the sediments involved and to further understand the geological and geomorphological context of the slope. This study is part of a larger multidisciplinary project, the results of which will also be presented in this paper. The landslide (rotational slide in the upper sector, developing into a translational slide in the lower part) affects Quaternary continental clastic deposits resting on a bedrock formed by Tertiary siliciclastic sediments of the Gorgoglione Flysch. TDR measurements did not show any significant movement during the period monitored (January 2013-January 2014). Slip zone geometries were hypothesized using inclinometric measurements taken from previous studies, stratigraphic data and geomorphological interpretations of topographic scarps. Feedback from monitoring will confirm this hypothesis.
\end{abstract}

\section{Introduction}

Landslides in urbanized environments can cause serious socioeconomic damage and loss of human life. As a result, scientific interest has increased and has focused on supporting technical studies using integrated methodologies, traditional and innovative techniques, and a scientific approach.

Our attention has been focused on a pilot area in the Agri Valley, Basilicata, southern Italy, on the left orographic side of the Agri River. The studied landslide affects a slope to the west of the town of Montemurro, a semi-urbanized environment where several anthropic buildings have suffered significant structural damage: old farmhouses showing evidence of reactivated movement over time; collapsed old dry stone walls; cracked natural spring fountains; and other fractured stone or masonry buildings. Roads, retaining walls and a tunnel were also damaged, creating traffic problems and public inconvenience. All of this has resulted in an increased interest in this landslide over the last few years.

Despite numerous studies during the last century, the complex geological and geomorphological framework of the area means the causes of movement affecting the slope and the slip depth are not yet fully understood. Further investigations were carried out in order to better understand geological context and geomorphological landslide characters, to reconstruct the stratigraphy of the soils in detail and to identify the slip zone(s) and its (their) relative depth. 


\section{Methodologies}

A detailed geological survey was performed, considering the landslide area and the surrounding slope sectors. Geomorphological analysis was carried out using field surveys and stereoscopic observations of aerial photographs from the Istituto Geografico Militare (IGM). Two series of photographs were used: (1) late summer 1985, 1 / 31000 scale, acquisition height of $5330 \mathrm{~m}$; (2) spring 2003, 1 / 30000 scale, acquisition height of $5000 \mathrm{~m}$.

Two geognostic boreholes (R1, $47.5 \mathrm{~m}$; R2, $40 \mathrm{~m}$ ) were drilled in order to reconstruct the stratigraphy of the deposits. A pre-existing geognostic borehole (S1), equipped with an inclinometer tube, provided indications of a slip zone, as reported by Summa et al. (2015) in this issue. However, the break of the inclinometer tube did not allow for further monitoring. As a result, boreholes R1 and R2 were also equipped with TDR (time domain reflectometry) sensors, in order to further evaluate depth and sliding geometry, identify any deeper slip zones and monitor movement.

Groundwater level fluctuations were determined over a hydrogeological year. Two measurements were taken, September 2012 and May 2013, and were considered to be representative of minimum and maximum aquifer recharge, respectively. The measurements were performed in boreholes R1 and R2 using piezometers, in other pre-existing geognostic boreholes and in all available water wells, providing the best possible distribution of the measuring points over the study area.

\section{Geological setting}

\subsection{The Agri Valley basin}

The Agri Valley basin is an inter-mountain basin belonging to the axial sector of the Southern Apennines (Fig.1), an eastverging fold-and-thrust belt developing as an accretionary wedge from late Oligocene to early Pleistocene due to the eastward migration of the Apenninic arc (e.g., Doglioni et al., 1996; Gueguen et al., 1997, 1998; Pescatore et al., 1999; Parotto and Praturlon, 2004; Bucci et al., 2012, 2014).

Lucanian Apennines tectono-stratigraphic units are derived from the Afro-Adriatic paleomargin deformation and are tectonically layered as follows: the Liguria-Piedmont Ocean units of the Liguride and Sicilide complex, from Cretaceous to Oligocene; Apennine Platform carbonate units, from Late Triassic to Tertiary; and the Lagonegro Basin units, from late Paleozoic to Tertiary (e.g., Scandone, 1967; Ogniben, 1969; D'Argenio et al., 1975; Mostardini and Merlini, 1986; Carbone et al., 1991; Roure et al., 1991; Monaco et al., 1998; Cello et al., 2000a; Menardi Noguera and Rea, 2000; Lentini et al., 2002; Tavarnelli and Prosser, 2003; Piedilato and Prosser, 2005). Thrust sheet top siliciclastic deposits (e.g., Gorgoglione Flysch) are emplaced by Ter- tiary upon tectonostratigraphic units indicated above (Carbone et al., 1991; Butler and Tavarnelli, 2006, and references therein).

The Agri Valley basin (Fig. 2) originates in the lower Pleistocene and results from phases of transtension and extension from early Pleistocene to Holocene with two high-angle fault systems, the Val d'Agri fault system described by Cello (2000), Cello et al. (2000a, b, 2003), Bucci et al. (2012, 2014), and references therein, along the NE flank of the basin, and the Monti della Maddalena fault system of Maschio et al. (2005), along the southern flank.

The basin is filled by continental clastic Quaternary units which overlay the pre-quaternary bedrock and are represented by coarse-grained slope deposits (Brecce di Galaino and Marsicovetere of Di Niro and Giano, 1995, and Brecce di Serra Mare of Boenzi et al., 2004) and clastic deposits from an alluvial and lacustrine environment (Complesso Val d'Agri of Di Niro et al., 1992, and Giano et al., 2000). The arrangement of these deposits suggests that five generations of slope and alluvial fan systems have developed along the eastern margin of the valley from Pleistocene to Holocene (Giano, 2011).

The interpretation of seismic surveys and electrical resistivity tomography (ERT) profiles in the Agri Valley basin allowed for the identification of the three fault-bounded depocenters: Molinara, Fossa del Lupo and Pertusillo (Fig. 2b), separated by the transversal intrabasinal highs of Monticello and Grumento (Morandi and Ceragioli, 2002; Lapenna and Rizzo, 2003; Colella et al., 2004; Rizzo et al., 2004).

\subsection{Geological background from previous studies}

The area surrounding the village of Montemurro is located near the Agri Valley Pertusillo depocenter, where the sediments of the "Agri Valley allogroup" crop out, as described by Zembo (2010), who proposed a new allostratigraphic model for the basin's deposits. The Agri Valley allogroup, up to $100 \mathrm{~m}$ thick, consists of four unconformity-bounded units, representing distinct depositional intervals related to regional tectonic and environmental changes, overlaying the lower Pleistocene deposits of the Spinoso conglomerate formation (Zembo et al., 2009; Zembo, 2010). From bottom to top, the Agri Valley allogroup is composed of Pietra del Pertusillo alloformation, Valle del Nasillo alloformation, Vallone dell' Aspro alloformation and Torrente Casale alloformation. This sequence reflects a progradation of fan systems in a lacustrine-palustrine setting, followed by expansion of a new alluvial-fluvial system (Zembo, 2010).

Carbone et al. (2010) recognized a Pietra del Pertusillo supersynthem on an unconformity-bounded stratigraphic unit including the Brecce di Galaino and the Conglomerati di La Serra (sensu Salvador, 1987), corresponding to the Spinoso conglomerate formation of Zembo (2010). The Pietra del Pertusillo supersynthem is composed of three synthems Grumento, Bosco dell'Aspro and Bosco San Lorenzo, from 


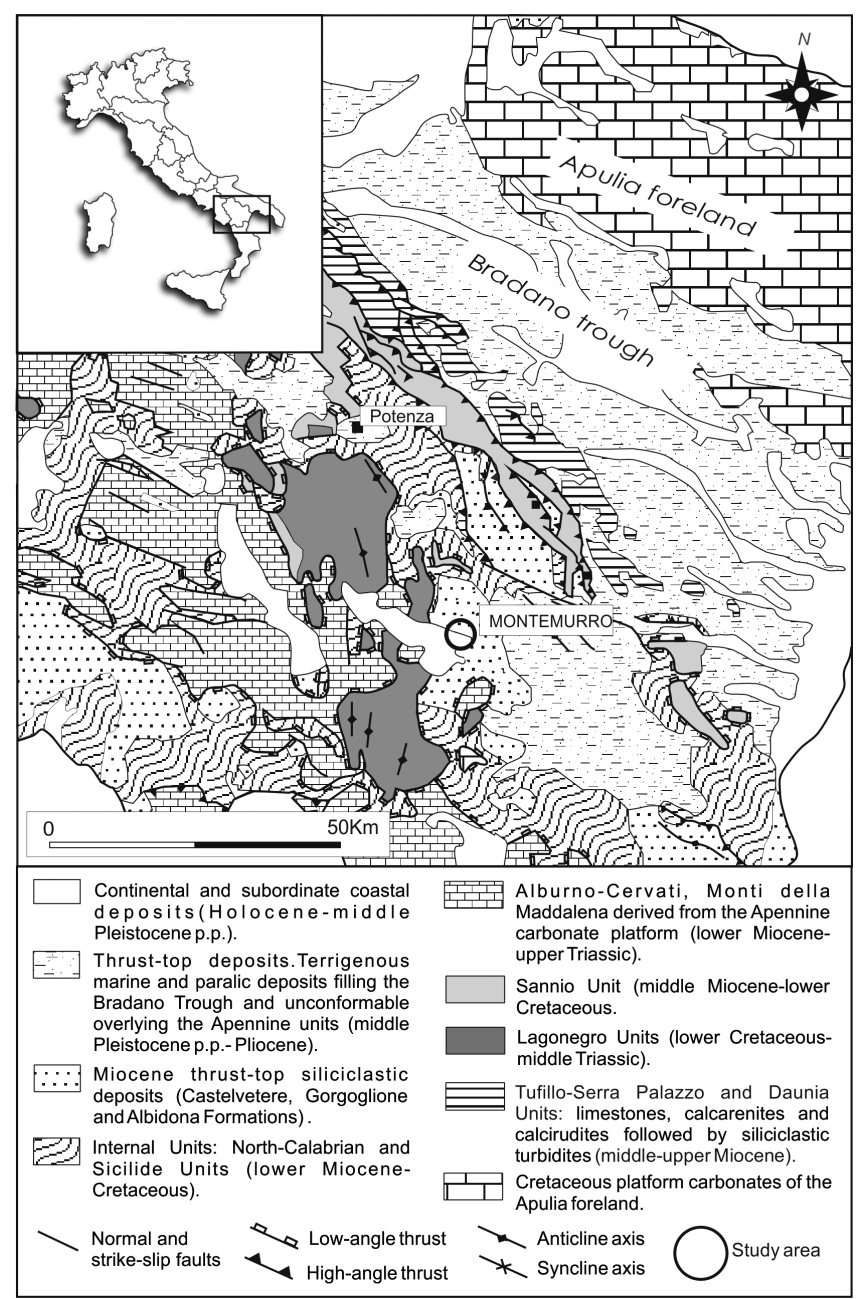

Figure 1. Geological sketch map of the Lucanian Apennines with the site of the study area (modified from Patacca and Scandone, 2007).

bottom to top, representative of coeval fluvial plain, alluvial fan and lacustrine deposits, respectively - and matches the Agri Valley allogroup of Zembo (2010) and the Complesso Val d'Agri of Di Niro et al. (1992), Di Niro and Giano (1995) and Boenzi et al. (2004).

In the Agri Valley basin, from Pleistocene to Holocene, Giano (2011) recognized five generations of slope and alluvial fan systems, consisting of coarse-grained slope and alluvial deposits with reddish paleosols interbedded with, or on top of, the sedimentary fans. The oldest fan system corresponds to the Spinoso conglomerate formation of Zembo (2010) and to the unconformity-bounded stratigraphic unit in which Carbone et al. (2010) included the Brecce di Galaino and the Conglomerati di La Serra, while the subsequent fan systems can be related to the Agri Valley allogroup deposits of Zembo (2010) and the Pietra del Pertusillo supersynthem of Carbone et al. (2010).

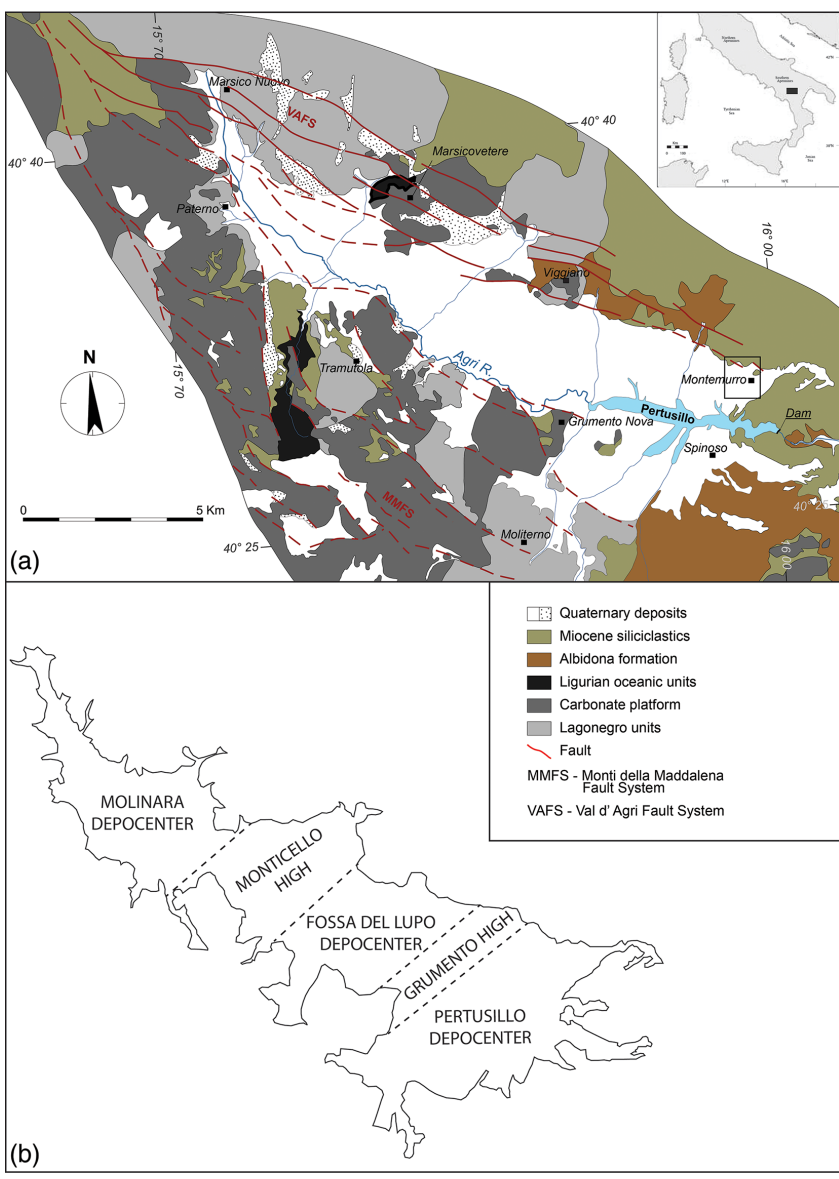

Figure 2. Geological sketch map of the Val d'Agri Basin (modified from Giocoli et al., 2015). Dashed black lines indicate the limits between highs and depocenters.

\section{New geological frameworkfrom field surveys}

The field surveys carried out during this work define a detailed geological setting of the area and recognize the reciprocal stratigraphic or tectonic contacts between the different outcropping formations, as shown in the sketch map and sketch section in Fig. 3.

In the studied area, mainly continental clastic Quaternary deposits of slope, alluvial and lacustrine environments outcrop. These deposits rest on a bedrock formed by the Tertiary siliciclastic sediments of the Gorgoglione Flysch, observed in several outcrops distributed mainly upstream from the village of Montemurro, and in the more engraved ditches.

The Gorgoglione Flysch formed from middle Langhian to lower Tortonian in a piggy-back trough during the Apennine orogeny compressional deformation phase producing the Irpinian Basin (Boenzi and Ciaranfi, 1970; Ciaranfi, 1972; Colella, 1979; Lentini et al., 1987; Carbone et al., 1988; Loiacono, 1993; Boiano, 1997; Butler and Tavarnelli, 2006). It consists of three sequences of terrigenous sediments (arenaceous and arenaceous-conglomeratic; arenaceous-marly; 


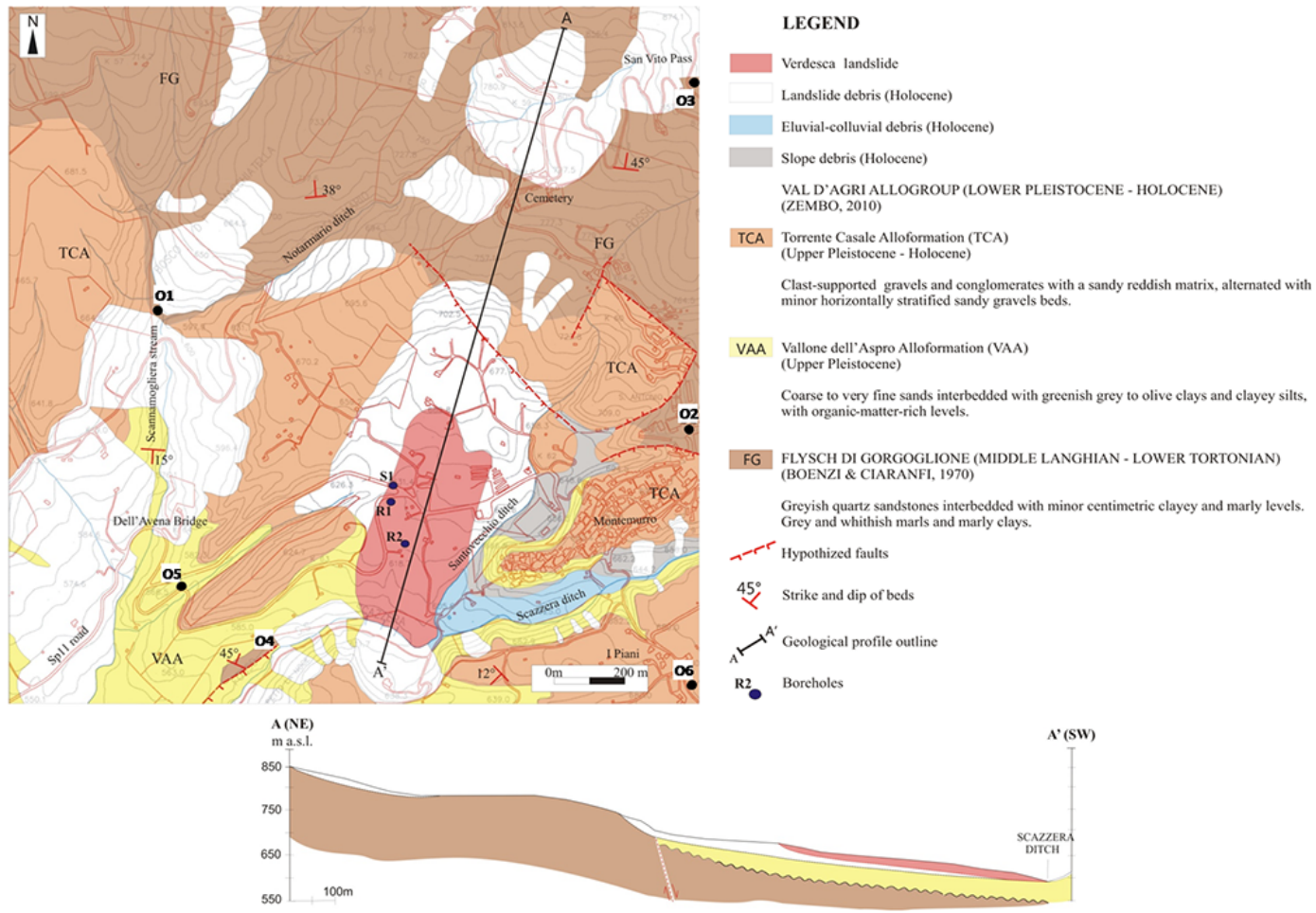

Figure 3. Geological sketch map and geological section $\left(\mathrm{A}-\mathrm{A}^{\prime}\right)$ of the study area. Letters $\mathrm{O} 1$ to $\mathrm{O6}$ indicate outcrops locations cited in the text, and boreholes are indicated as S1, R1 and R2.

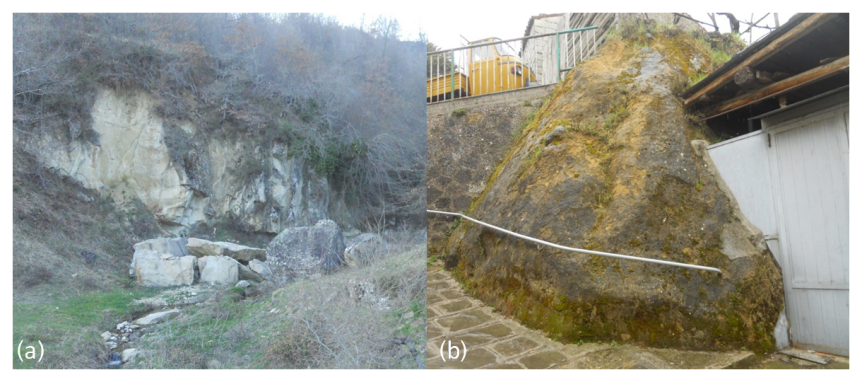

Figure 4. Outcrops of the Gorgoglione Flysch pelitic-arenaceous sequence at the confluence between Scannamogliera and Notarmario streams (a) and in the village of Montemurro (b), where several buildings rest upon massive sandstones.

silty-arenaceous-marly), interbedded and repeated several times at different stratigraphic heights, marking several pulsating turbiditic events (Boenzi et al., 1968; Boenzi and Ciaranfi, 1970; Critelli and Loiacono, 1988; Mutti and Normark, 1987). In the studied area the pelitic-arenaceous sequence prevails. The main outcrops are upstream from the village of Montemurro, close to the San Vito Pass, and along a large section extending from the village's cemetery to the Scannamogliera stream. Other outcrops affect all the incisions of this stream, up to the confluence of the Notarmario ditch, where one of the best exposures can be seen (outcrop O1, Fig. 4a). The northern part of the village is

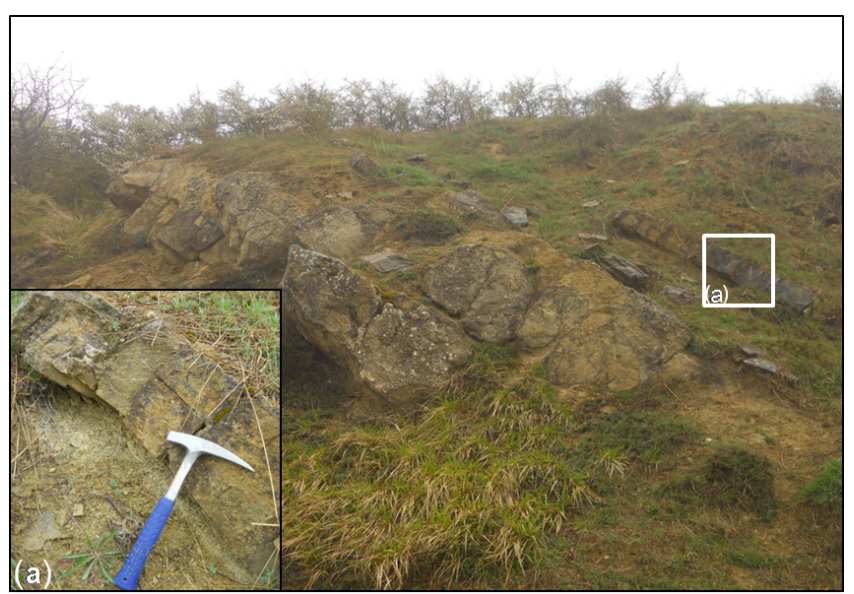

Figure 5. Outcrop of the Gorgoglione Flysch pelitic-arenaceous sequence at the San Vito Pass. Grey or yellowish sandstones and grey or brown silty marls and silty clays are interbedded. In the zoom box (a) the very sharp contact between sandstones and the underlying pelitic level is shown

also located on the Gorgoglione Flysch, with several buildings directly resting on massive sandstones (outcrop $\mathrm{O} 2$, Fig. 4b). The pelitic-arenaceous sequence, exposed in these outcrops, is mainly composed of grey, yellowish or whitish quartz-feldspar sandstones, with grey or brown silty marls 


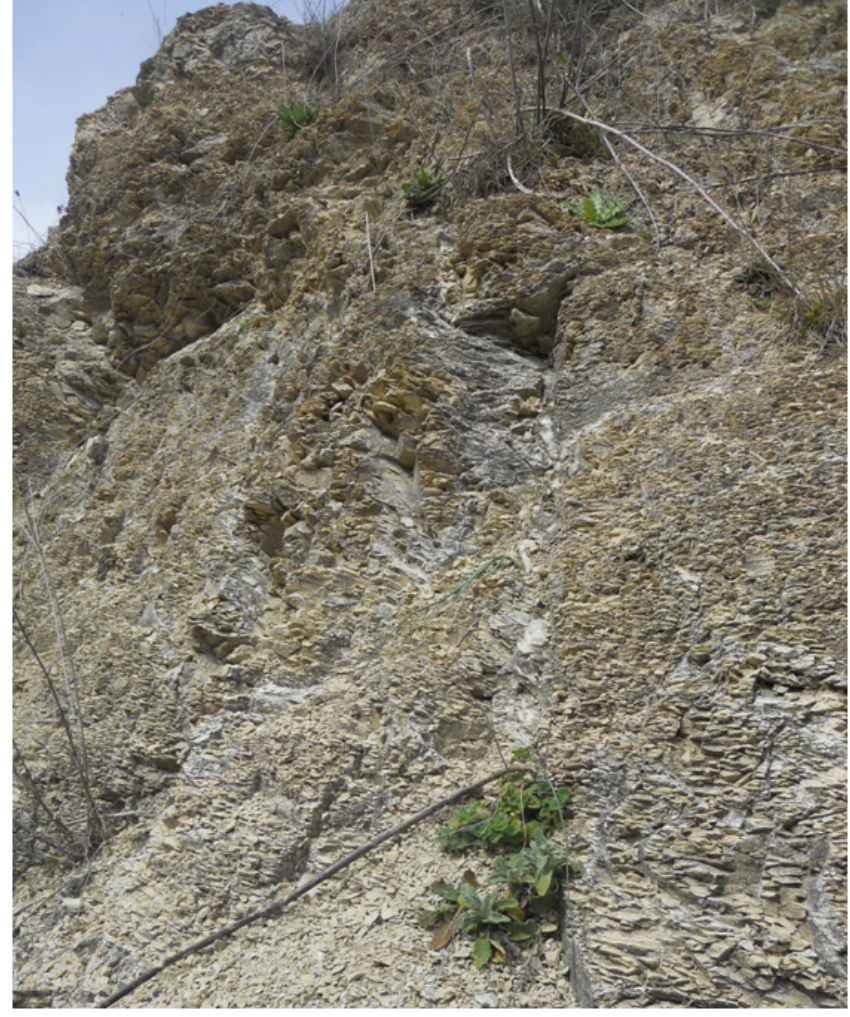

Figure 6. Exposure of the Gorgoglione Flysch arenaceous-marly sequence. Grey and whitish marls, silty marls and marly clays, strongly fragmented in slivers and scraps.

and interbedded silty clays. The decimetric to metric sandstone banks often show yellow ochre surfaces altered with whitish veins, carbonatic-cement-filled, and a graded vertical bedding characterized by breccias with millimeter- and centimeter-diameter pebbles at the base. These basal breccias rest on the underlying pelitic level with a very sharp contact, while the transition upward to the finer upper level is more gradual (outcrop O3, Fig. 5).

An isolated outcrop representative of the arenaceousmarly sequence is located on the right orographic side of the Scazzera ditch, SW of the village of Montemurro. It is characterized by grey and whitish marls, silty marls and marly clays, strongly interbedded and fragmented in slivers and scraps, due to intense tectonic deformation (outcrop O4, Fig. 6).

In the study area the continental clastic Quaternary sequence rests on an angular unconformity truncating the Miocene bedrock, as shown in the geological sketch section in Fig. 3. It is represented by alluvial fan, alluvial plain and lacustrine deposits, corresponding to the middle and upper intervals of the Complesso Val d'Agri of Di Niro et al. (1992) and to the Vallone dell'Aspro and Torrente Casale alloformations of Zembo (2010).

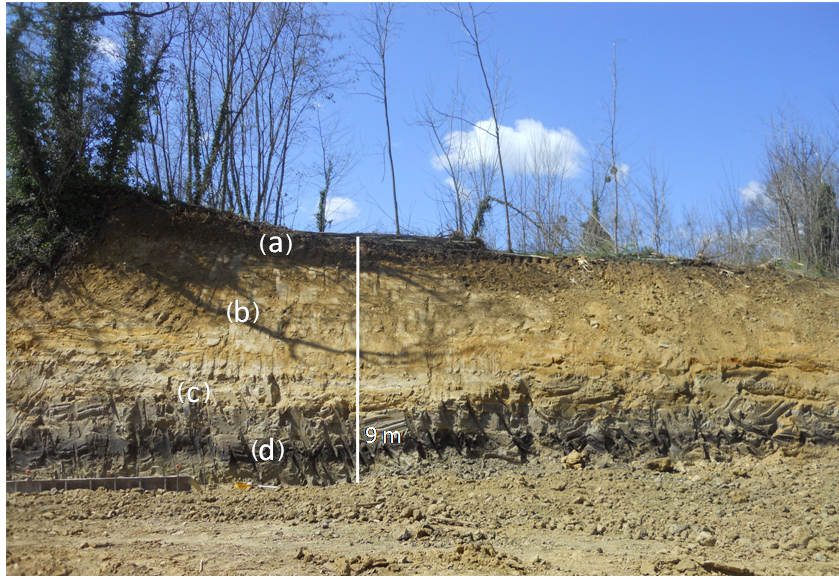

Figure 7. Artificial scarp along the SP11 road, with a representative exposure of the Vallone dell'Aspro deposits. Below a $1 \mathrm{~m}$ thick soil (a) there are pebbly sands (b) and grey clayey silts (c). A very dark $40 \mathrm{~cm}$ thick, organic-matter-rich peaty level can be observed near the base of the outcrop (d).

Most of the Pleistocene deposits affecting the study area can be attributed to the Vallone dell'Aspro alloformation, characterized by coarse to fine sands and stratigraphically lower greenish to grey silty clay and clayey silts, interbedded with organic-rich peaty levels. Both upward and downward, along the stratigraphic sequence, clast-supported coarse conglomerates and sandy gravels can be observed. The upper conglomerates show imbricated pebbles of different composition, mainly arenaceous and subordinately siliceous and igneous, while the composition of the lower gravels, often characterized by a reddish sandy matrix, is mainly dolomitic, calcitic, siliceous and arenaceous, with rarer clasts of varicolored argillites and metamorphic rocks (Zembo, 2010). This alloformation corresponds to an axial braided alluvial system where the water and sediment supply was from both the mainstream and transverse alluvial fans. This environment was also characterized by fossil-refilled channels, pools and ponds; temporary lacustrine-palustrine settings associated with flood events; interfluves areas, as shown by the accumulations of mollusk assemblages typical of open vegetated zones; organic layers representative of a standing swamp area; and flash-flood-laminated structures (Beraldi-Campesi et al., 2006; Pisegna Cerone, 2008; Zembo, 2010).

The Vallone dell'Aspro alloformation's most representative outcrop is on an artificial scarp along the SP11 road, at $580 \mathrm{~m}$ a.s.l., in the Dell'Avena Bridge area, on the right orographic side of a small incision tributary of the Scannamogliera stream (outcrop O5, Fig. 7). This artificial scarp was excavated during the construction of a new road and allowed for the observation of freshly exposed sandy and clayey deposits outcropping in the area. Below a $1 \mathrm{~m}$ thick soil there are massive to crudely laminated pebbly sands with matrix-supported gravelly levels. Downward, the sands show 


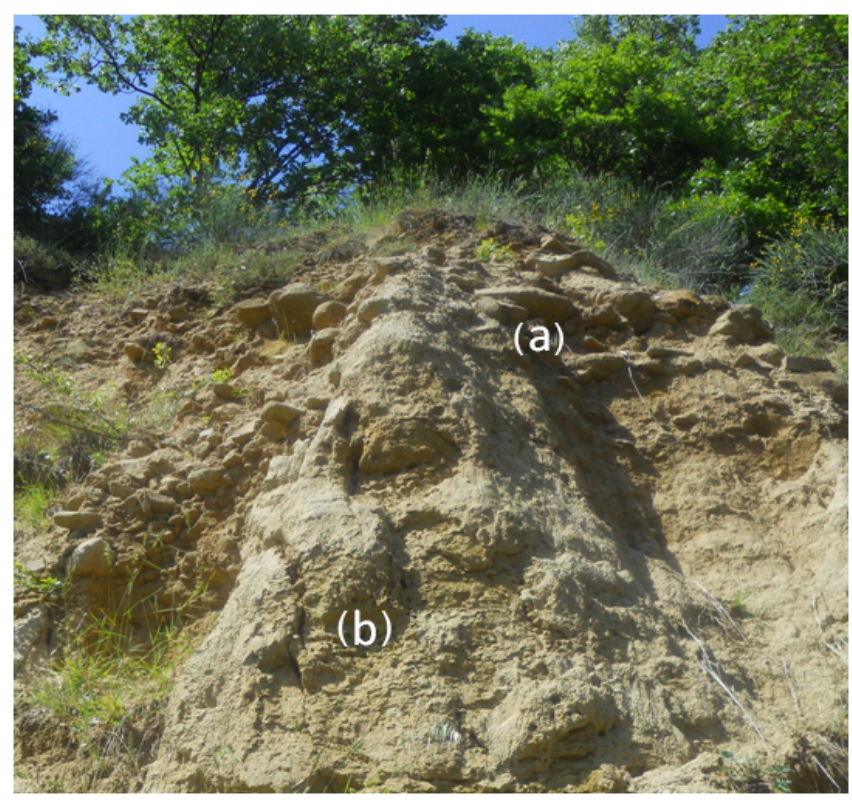

Figure 8. Representative outcrop of the Torrente Casale alloformation. Clast-supported massive conglomerates (a) upon sandy gravels and gravelly sands (b).

reddish ferruginous concretions and more calcareous whitish levels and vegetal fragments. The grain-size finer facies of the Vallone dell'Aspro alloformation is represented in this outcrop by grey clayey silts with a progressive downward darkening due to the increase of the organic matter content, with a $40 \mathrm{~cm}$ thick peaty level. It contains vegetal fragments and plant frustules, and it shows, on the fresh exposure, a very dark coloring due to its very high organic matter content. This coloring decreased over the months, due to oxidative processes involving organic matter.

The Vallone dell'Aspro alloformation's coarser conglomeratic and gravelly component outcrops along the Scannamogliera stream, mainly on its right orographic side. The best outcrop can be observed upstream from the Dell'Avena Bridge, at $570 \mathrm{~m}$ a.s.l., and is characterized by clast-supported conglomerates, with a reddish matrix and millimeter- to centimeter-thick polygenic clasts, interbedded with thin silty and arenaceous beds. Exposures of sands and gravels also outcrop on the vertical or sub-vertical walls delimiting the topographic highs where the village of Montemurro and some of its rural settlements are located. These walls expose yellow ochre laminated or massive sandy silts and silty sands interbedded with centimeter- to decimeterthick sandy matrix gravelly levels containing polygenic and polymictic clastic components.

The Torrente Casale alloformation crops out only in the topographically higher areas, with several outcrops observed, mainly on the left orographic side of the Notarmario ditch, in the I Piani area, and along the Santovecchio stream.
The most representative outcrop of these deposits is in the I Piani area, at $671 \mathrm{~m}$ a.s.l., where a sequence of about $12 \mathrm{~m}$ can be observed (outcrop O6, Fig. 8). This outcrop shows, below a metric soil coverage, clast-supported massive conglomerates, with a yellowish sandy matrix and a heterometric cobble- to boulder-sized clastic component, represented mainly by the sandstones of the Gorgoglione Flysch and the Albidona Formation cherts, and igneous and metamorphic clasts. The sandy component increases downward and appears as matrix-supported sandy gravels with polygenic millimeter- to centimeter-thick clasts, and as yellow ochre sands. The same characters can be recognized in other outcrops in the study area.

The contact between the Torrente Casale and Vallone dell'Aspro alloformation deposits is a composite surface, erosional in the north and depositional towards the basin, based upon a weathering profile composed of a fersiallitic/brunified pedocomplex with two paleosols corresponding with two erosion episodes (Zembo, 2010). In the study area, this surface can be observed, though it is laterally discontinuous, at about $650 \mathrm{~m}$ a.s.l., at the top of the vertical walls on the left orographic side of the Scazzera stream, and it shows a moderate rubification due to iron and manganese oxides and hydroxides.

The Quaternary continental deposits, which stratigraphically overlay the Miocene bedrock in an onlap relationship, are plan-parallel, arranged in subhorizontal to gently southdipping strata towards the basin depocenter.

\section{Geomorphological setting}

Results of the geomorphological analysis carried out in the area studied are reported in the geomorphological sketch map shown in Fig. 9.

The western side of the village of Montemurro is characterized by an obvious slope change controlled by the different strength of the outcropping lithologies. The presence of alternating turbidite sandstones, siltstones and silty clays in the northern sector produces steeper slopes than the southern sector, where Quaternary deposits consisting of conglomerates, sands and clays occur. The area is characterized by a wide geomorphological instability involving the entire slope from the Scazzera stream, 810 to $590 \mathrm{~m}$ above sea level and $1500 \mathrm{~m}$ in length.

Landslides affect mainly Quaternary continental deposits of the Val d'Agri Basin and also, in the topmost slope sector, the Gorgoglione Flysch sandstones. In some cases, it is possible to recognize landslide main scarps, minor scarps, terrace-like features and counter-slopes, which are particularly pronounced along the southern sector of the slope. Geomorphological trenches in the foothills of fault scarps and landslide niches have also been observed.

An impressive pre-1954 quiescent landslide involved the entire area delimited by the road from Montemurro to the 


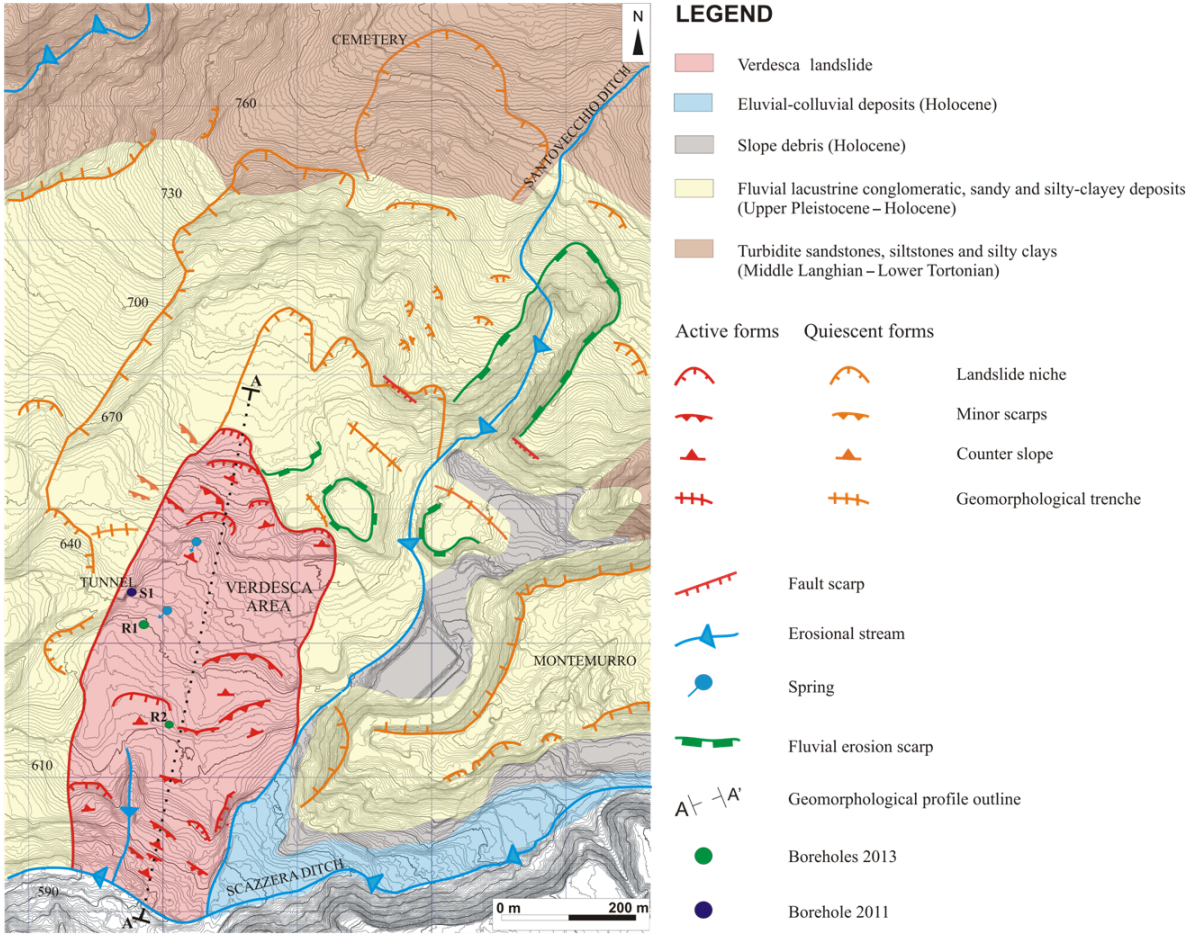

Figure 9. Geomorphological sketch map. The geomorphological profile outline along the $\mathrm{A}-\mathrm{A}^{\prime}$ trace is illustrated in Fig. 13.

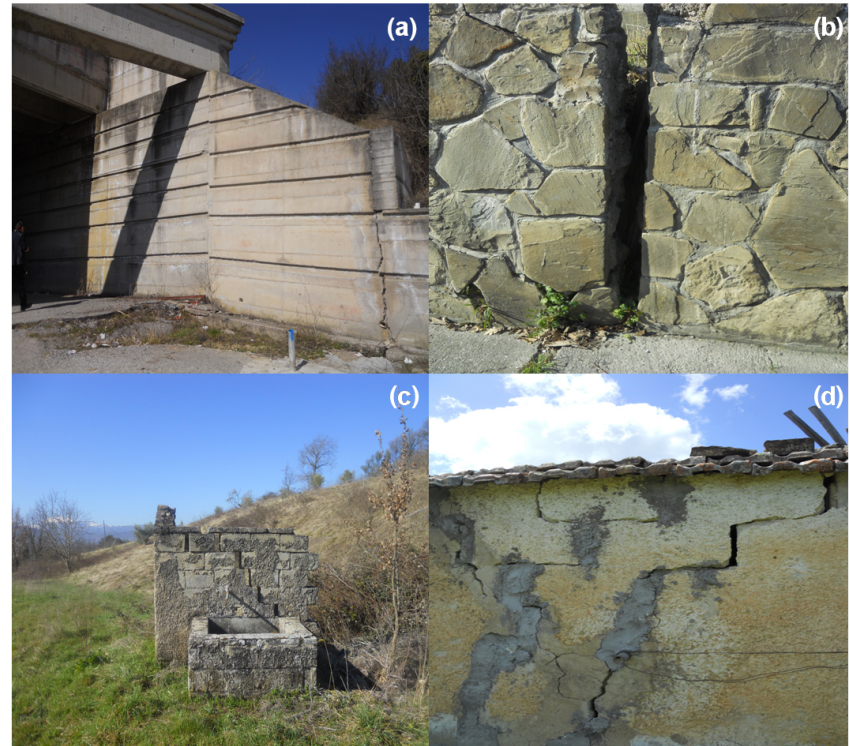

Figure 10. Evidence of deformation and warping on the road tunnel (a), retaining walls (b), and old building (c-d).

cemetery to the north, by the Montemurro high to the east, by the conoid southwestward of the cemetery to the west and by the Scazzera ditch to the south. The damaged area is about 40 ha, and subsoil geological structures have been completely reworked and altered. The entire area is still active and has been affected by many smaller landslide events.
Now, the main landslide activity affects the slope in the Verdesca area, where significant evidence of ongoing activity has been observed; this consists of structural damage to infrastructure and anthropic buildings (e.g., dislocation of SP11 road tunnel box; warping of retaining walls; and deformation of road embankments, road surfaces and old manmade structures; Fig. 10; Bentivenga et al., 2012).

The area is affected by a complex landslide, about $700 \mathrm{~m}$ long and $325 \mathrm{~m}$ wide, developed between 675 and $590 \mathrm{~m}$ a.s.l., with a maximum elevation difference of about $85 \mathrm{~m}$ between the upper and the lower portions of the landslide body. The size of the damaged area is about 20 ha. The steepness of the landslide body in the accumulation area is about $14^{\circ}$, while it is about $12^{\circ}$ in the source area.

In the upper sector this landslide is a rotational slide, evolving, in the lower part, into a translational slide (Varnes, 1978; Cruden and Varnes, 1996). The landslide foot has been affected by further superficial movements, due to the continuous erosion of the Scazzera stream, whose course is diverted in relation to the zone accumulation. Two piezometric surfacing springs were identified inside the landslide, in relation to minor scarps.

\section{Stratigraphies and geognostic investigations}

The main features of the stratigraphic logs reconstructed along the R1 and R2 boreholes are shown in Fig. 11. 


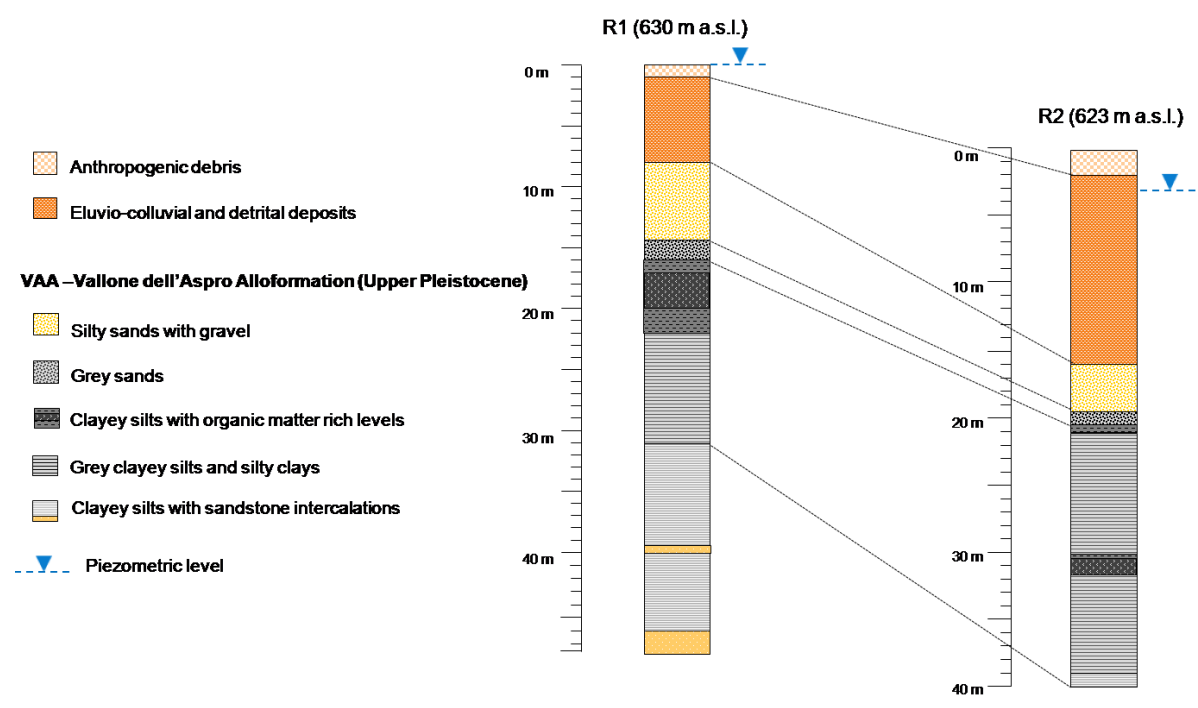

Figure 11. Main stratigraphic features of the logs reconstructed along the R1 and R2 boreholes, showing a sequence of sandy and silty sediments resting on clayey silts with blackish peaty levels.
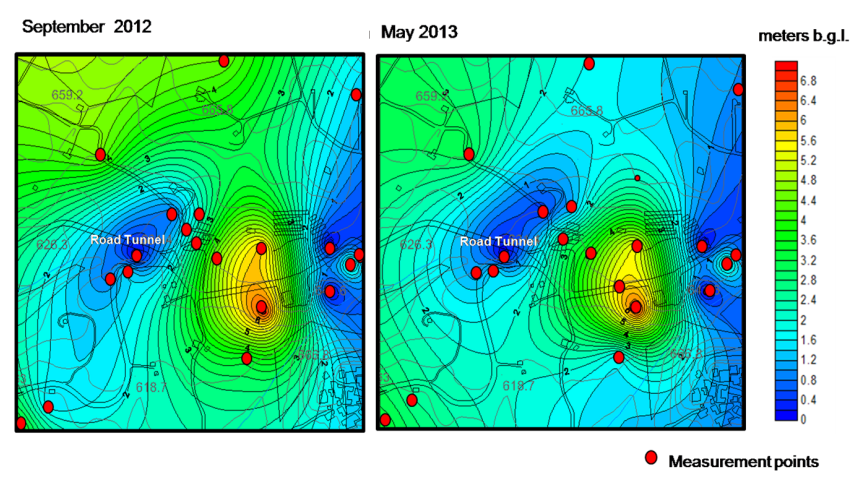

Figure 12. Isopiezometric maps. Groundwater is consistently close to ground level, and little fluctuations were identifed between the periods of maximum and minimum acquifer recharge.

The first sediments found were attributed to eluviocolluvial and detritic deposits, with thickness increasing downstream up to a maximum of $14 \mathrm{~m}$ in borehole R2. Below these deposits, sandy-silty sediments were observed, with a clayey component strongly varying with depth. The predominant yellow ochre coloring is due to the high weathering rate, favored by the significant deconstruction of the sediments and the groundwater circulation. In the borehole, the coarser silty-sandy sediments switch to clayey silts, with several interbedded blackish peaty levels, at several stratigraphic depths. This transition shows a deepening downstream, dropping from 16 to $20.5 \mathrm{~m}$ below ground level. Silty levels affected by dark nodules and blackish saline concretions can also be observed, respectively due to oxidation phenomena and solution-precipitation processes favored by groundwater circulation. These stratigraphic logs are consistent with that of the S1 borehole, described by Summa et al. (2015). The clastic component increases with depth, anticipating the appearance of sandstone strata at about $40 \mathrm{~m}$ depth in borehole R1.

From a hydrogeological point of view, groundwater is consistently close to ground level, and fluctuations of a few centimeters were identified between the periods of maximum and minimum aquifer recharge. The anomalously higher values of the groundwater level in the central sector of the area studied are probably linked to engineering draining actions carried out in the past along the provincial road. The isopiezometric maps are shown in Fig. 12.

TDR measurements were carried out every 2 months from January 2013 until January 2014, using a Megger 2000 instrument and a RG-58 rigid coaxial cable for deformation measurements with a tinned copper inner conductor $(50 \mathrm{ohm})$ and PVC jacket installed in both R1 and R2 boreholes. Instrumental accuracy was $0.1 \%$ of range. However no significant movement was detected.

\section{Discussion and conclusions}

Field surveys and stratigraphic interpretations of geognostic boreholes enabled us to define a detailed geological, geomorphological and hydrogeological framework of the study area; to understand some important features of the landslide; and to reconstruct the trend of the slip zone.

The slope studied is affected by a strong Quaternary morphodynamic, with several sequential events involving the Miocene siliciclastic deposits of the Gorgoglione Flysch, which represent the pre-Quaternary bedrock, and Quaternary clastic sediments of the Agri Valley allogroup (Torrente Casale and Vallone dell'Aspro alloformation). 


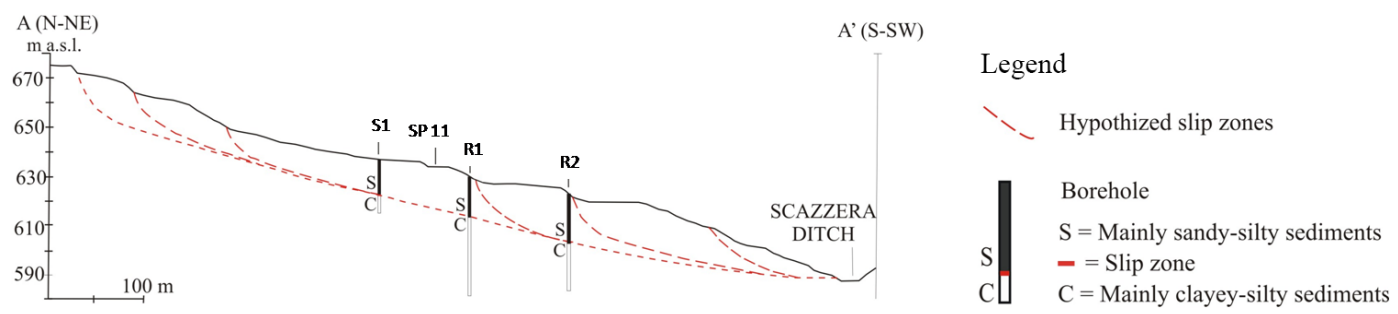

Figure 13. Geomorphological profile (outline A-A' in Fig. 9) with the trend of the slip zones, hypothesized considering lithological information from boreholes and geomorphological interpretation of topographic scarps.

A more significant outcrop of the Vallone dell'Aspro alloformation in the area studied shows a sequence of sandy and silty sediments resting on clayey silts, with a blackish peaty level. The investigated sequence is consistent with that reconstructed along boreholes R1 and R2: from this analogy, it is possible to ascribe the sediments affected by the landslide studied, in total or partly, to the finer facies of the Vallone dell'Aspro alloformation. These sediments can be considered saturated during the entire hydrogeological year, principally in relation to the areas showing more significant evidence of instability, such as that of the road tunnel (Verdesca area).

The Verdesca landslide is complex, being characterized by a rotational slip evolving downstream into a translational slip. Recent movements involving a road tunnel, retaining walls and other manmade structures cracked an inclinometer tube in a pre-existing borehole at $14.3 \mathrm{~m}$ depth located near the road tunnel, allowing for the identification of a slip zone at that depth (Summa et al., 2015).

We reported in the geomorphological profile $\mathrm{A}-\mathrm{A}^{\prime}$ (Fig. 13) the trend of the hypothesized slip zones, considering both lithological transition (also easily identified in boreholes R1 and R2 at a depth ranging between 16 and $20.5 \mathrm{~m}$ below ground level) and the geomorphological interpretation of topographic scarps.

Only further TDR measurements will make it possible for us to confirm or modify the hypothesized slip zone geometries, as no significant movements were detected in the monitored period (January 2013-January 2014). In this phase, pending direct feedback from TDR monitoring, geomorphological reconstruction of the slip zones and stratigraphic interpretations of geognostic holes have been valuable support tools for defining the slip of the landslide studied and for planning technical interventions aimed at mitigating risk and preserving existing manmade structures.

Acknowledgements. We thank E. Norelli for his positive and constructive discussions. We dedicate this paper to Ivana Adurno; with her strength, her joy and will for life she has been a model for all of us.

Edited by: V. Lapenna

\section{References}

Bentivenga, M., Palladino, G., and Caputi, A.: Development of the Pietra Maura landslide and interactions with the Marsico Nuovo dam (Basilicata - Italy), Geogr. Fis. Din. Quat., 35, 1322, doi:10.4461/GFDQ.2012.35.2, 2012.

Beraldi-Campesi, H. B., Cevallos-Ferriz, S. R. S., Centeno-Garcia, E., Arenas-Abad, C., and Fernandez, L. P.: Sedimentology and paleoecology of an Eocene-Oligocene alluvial-lacustrine arid system, Southern Mexico, Sediment. Geol., 191, 227-254, 2006.

Boenzi, F., Capolongo, D., Cecaro, G., D’Andrea, E., Giano, S. I., Lazzari, M., and Schiattarella, M.: Evoluzione geomorfologica polifasica e tassi di sollevamento del bordo sud-occidentale dell'alta Val d'Agri (Appennino Meridionale), Boll. Soc. Geol. Ital., 123, 357-372, 2004.

Boenzi, F. and Ciaranfi, N.: Stratigrafia di dettaglio del "Flysch di Gorgoglione” (Lucania), Memorie della Società Geologica Italiana, 9, 65-79, 1970.

Boenzi, F., Ciaranfi, N., and Pieri, P.: Osservazioni geologiche nei dintorni di Accettura e di Oliveto Lucano, Memorie della Società Geologica Italiana, 7, 379-392, 1968.

Boiano, U.: Anatomy of a siliciclastic turbidite basin: the Gorgoglione Flysch, Upper Miocene, southern Italy: physical stratigraphy, sedimentology and sequence stratigraphy framework, Sed. Geol., 107, 231-262, 1997.

Bucci, F., Novellino, R., Guglielmi, P., Prosser, G., and Tavarnelli, E.: Geological map of the northeastern sector of the high Agri Valley, Southern Apennines (Basilicata, Italy), J. Maps, 8, 282 292, 2012.

Bucci, F., Novellino, R., Tavarnelli, E., Prosser, G., Guzzetti, F., Cardinali, M., Gueguen, E., Guglielmi, P., and Adurno, I.: Frontal collapse during thrust propagation in mountain belts: a case study in the Lucania Apennines, Southern Italy, J. Geol. Soc., London, doi:10.1144/jgs2013-103, in press, 2014.

Butler, R. W. H. and Tavarnelli, E.: The structure and Kinematics of substrate entrainment into high-concentration sandy turbidites: a field example from Gorgoglione "flysch" of southern Italy, Sedimentology, 53, 655-670, 2006.

Carbone, S., Catalano, S., Lentini, F., and Monaco, C.: Le unità stratigrafico-strutturali dell'Alta Val d'Agri (Appennino Lucano) nel quadro della evoluzione del sistema catena-avanfossa, Memorie della Società Geologica Italiana, 41, 331-341, 1988.

Carbone, S., Catalano, S., Lazzari, S., Lentini, F., and Monaco, C.: Presentazione della carta geologica del Bacino del fiume Agri (Basilicata), Memorie della Società Geologica Italiana, 47, 129 143, 1991. 
Carbone, S., Giano, S. I., Lentini, F., and Tescione, M.: Expanatory notes of the Italian Geological Map to $1: 50000$ map scale. Sheet 505 Moliterno, ISPRA, Dipartimento Difesa Del Suolo, Servizio Cartografico, Relazioni e Documentazioni di Base, Roma, Italy, $1-107,2010$.

Cello, G.: A quantitative structural approach to the study of active fault zone in the Apennines (Peninsular Italy), J. Geodyn., 29, 265-292, 2000.

Cello, G., Gambini, R., Mattioni, L., Mazzoli, S., Read, A., Tondi, E., and Zucconi V.: Geological analysis of the High Agri Valley (Lucanian Apennines, Southern Italy), Memorie della Società Geologica Italiana, 55, 149-155, 2000a.

Cello, G., Gambini, R., Mazzoli, S., Read, A., Tondi, E., and Zucconi, V.: Fault zone characteristics and scaling properties of the Val d'Agri Fault System (Southern Apennines, Italy), J. Geodyn., 29, 293-307, 2000b.

Cello, G., Tondi, E., Micarelli, L., and Mattioni, L.: Active tectonics and earthquake sources in the epicentral area of the 1857 Basilicata earthquake (southern Italy), J. Geodyn., 36, 37-50, 2003.

Ciaranfi, N.: Il Flysch di Gorgoglione, Boll. Serv. Geol. It., 92, 101114, 1972.

Colella, A.: Medium-scale tractive bedforms and structures in Gorgoglione Flysch (lower Miocene; Southern Apennines, Italy), Boll. Soc. Geol. Ital., 98, 483-494, 1979.

Colella, A., Lapenna, V., and Rizzo, E.: High-resolution imaging of the High Agri Valley basin (southern Italy) with electrical resistivity tomography, Tectonophysics, 386, 29-40, 2004.

Critelli, S. and Loiacono, F.: Provenienza e dispersione dei sedimenti nel Flysch di Gorgoglione (Langhiano-Tortoniano, Appennino Lucano); implicazioni sull'evoluzione delle mode detritiche arenacee nell'orogene sudappenninico, Memorie della Società Geologica Italiana, 41, 809-826, 1988.

Cruden, D. M. and Varnes D. J.: Landslide types and processes, in: Landslides: Investigation and Mitigation, Transportation Research Board Special Report, 247, edited by: Turner A. K. and Schuster R. L., National Accademy Press, Washington D.C., 3675, 1996.

D’Argenio, B., Pescatore, T., and Scandone, P.: Structural pattern of the Campania-Lucania Apennines, Quaderni di Ricerca Scientifica, 90, 313-327, 1975.

Di Niro, A. and Giano, S. I.: Evoluzione geomorfologica del bordo orientale dell'Alta Val d'Agri (Basilicata), Studi Geologici Camerti, Special Issue 1995/2, 207-218, 1995.

Di Niro, A., Giano, S. I., and Santangelo, N.: Primi dati sull'evoluzione geomorfologica e sedimentaria del bacino dell'alta Val d'Agri (Basilicata), Studi Geologici Camerti, Special Issue 1992/1, 257-263, 1992.

Doglioni, C., Harabaglia, P., Martinelli, G., Mongelli, F., and Zito, G.: A geodynamic model of the Southern Apennines accretionary prisms, Terra Nova, 8, 540-547, 1996.

Giano, S. I.: Quaternary alluvial fan systems of the Agri intermontane basin (southern Italy): tectonic and climatic control, Geol. Carpath., 62, 65-76, 2011.

Giano, S. I., Maschio, L., Alessio, M., Ferranti, L., Improta, S., and Schiattarella, M.: Radiocarbon dating of active faulting in the Agri high valley, southern Italy, J. Geodyn., 29, 371-386, doi:10.1016/S0264-3707(99)00058-7, 2000.

Giocoli, A., Stabile, T. A., Adurno, I., Perrone, A., Gallipoli, M. R., Gueguen, E., Norelli, E., and Piscitelli, S.: Geological and geo- physical characterization of the southeastern side of the High Agri Valley (southern Apennines, Italy), Nat. Hazards Earth Syst. Sci., 15, 315-323, doi:10.5194/nhess-15-315-2015, 2015.

Gueguen, E., Doglioni, C. and Fernandez, M.: Lithospheric boudinage in the Western Mediterranean back-arc basins, Terra Nova, 9, 184-187, 1997.

Gueguen, E., Doglioni, C., and Fernandez, M: On the post-25 Ma geodynamic evolution of the Western, Tectonophysics, 298, 259269, 1998.

Lapenna, V. and Rizzo, E.: Tomografie geoelettriche dipolari del bacino dell'Alta Val d'Agri, in: Le Risorse Idriche Sotterranee dell'Alta Val d'Agri, Autorità Interregionale di Bacino della Basilicata, Potenza, Italy, 87-111, 2003.

Lentini, F., Carbone, S., Catalano, S., and Monaco, C.: Confronti sedimentologici-petrografici e posizione strutturale dei Flysch di Albidona e di Gorgoglione nella media Val d'Agri (Appennino lucano), Memorie della Società Geologica Italiana, 38, 259-273, 1987.

Lentini, F., Carbone, S., Di Stefano, A., and Guarnieri, P.: Stratigraphical and structural constraints in the Lucanian Apennines (Southern Italy): tools for reconstructing the geological evolution, J. Geodyn., 34, 141-158, 2002.

Loiacono, F.: Geometrie e caratteri deposizionali dei corpi arenacei nella successione stratigrafica del Flysch di Gorgoglione (Miocene superiore, Appennino meridionale), Boll. Soc. Geol. Ital., 112, 909-922, 1993.

Maschio, L., Ferranti, L., and Burrato, P.: Active extensional in Val d'Agri area, Southern Apennines, Italy: implications for the geometry of the seismogenic belt, Geophys. J. Int., 162, 591-609, 2005.

Menardi Noguera, A. and Rea, G.: Deep structure of the Campanian-Lucanian Arc (Southern Apennine, Italy), Tectonophysics, 324, 239-265, 2000.

Monaco, C., Tortorici, L., and Paltrinieri, W.: Structural evolution of the Lucanian Apennines, Southern Italy, J. Struct. Geol., 20 617-638, 1998.

Morandi, S. and Ceragioli, E.: Integrated interpretation of seismic and resistivity images across the "Val d'Agri" graben (Italy), Ann. Geophys., 45, 259-271, 2002,

http://www.ann-geophys.net/45/259/2002/.

Mostardini, F. and Merlini, S.: Appennino centro meridionale. Sezioni geologiche e proposta di modello strutturale, Memorie della Società Geologica Italiana, 35, 177-202, 1986.

Mutti, E. and Normark, W. R.: Comparing examples of modern and ancient turbidite systems: problems and concepts, in: Marine clastic sedimentology, edited by: Leggett, J. K. and Zuffa, G. G., Graham and Trotman, London, 1-38, 1987.

Ogniben, L.: Schema introduttivo alla geologia del confine calabrolucano. Memorie della Società Geologica Italiana, 8, 453-763, 1969.

Parotto, M. and Praturlon, A.: The Southern Apennines arc, in: Geology of Italy, Special Volume of the Italian Geological Society for the IGC 32 Florence-2004, edited by: Crescenti, V., D’Offizi, S., Merlino, S., and Sacchi, L., 33-58, 2004.

Patacca, E. and Scandone, P.: Geology of Southern Apennines, in: Results of the CROP Project, Sub-project CROP-04 So, Spec. Issue 7, edited by: Mazziotti, A., Patacca, E., Scandone, S., Roma, Soc. Geol. It., 75-119, 2007. 
Pescatore, T., Renda, P., Schiattarella, M., and Tramutoli, M.: Stratigraphic and structural relationships between Meso-Cenozoic Lagonegro basin and coeval carbonate platforms in Southern Apennines, Italy, Tectonophysics, 315, 269-286, 1999.

Pisegna Cerone, E.: I molluschi continentali delle successioni medio-pleistoceniche dell'Italia cento-meridionale: Paleoecologia e Biocronologia, $\mathrm{PhD}$ thesis, Università degli Studi di Modena, 2008.

Piedilato, S. and Prosser, G.: Thrust sequences and evolution of the external sector of a fold and thrust belt: example from the Southern Apennines (Italy), J. Geodyn., 39, 386-402, 2005.

Rizzo, E., Colella, A., Lapenna, V., and Piscitelli, S.: Highresolution imaging of the fault-controlled High Agri Valley basin (Southern Italy) with deep and shallow electrical resisitivity tomographies, Phis. Chem. Earth, 29, 321-327, 2004.

Roure, F., Casero, P., and Vially, R.: Growth processes and mélange formation in the Southern Appennines accretionary wedge, Earth Planet. Sci. Lett., 102, 395-412, 1991.

Salvador, A.: Unconformity-bounded stratigraphic units, Geol. Soc. Am. Bull., 98, 232-237, 1987.

Scandone, P.: Studi sulla geologia lucana: la serie calcareo-silicomarnosa e i suoi rapporti con l'Appennino Calcareo, Bollettino della Società dei Naturalisti in Napoli, 76, 1-175, 1967.
Summa, V., Margiotta, S., Colaiacovo, R., and Giannossi, M. L.: The influence of the grain-size, mineralogical and geo-chemical composition on the Verdesca landslide, Nat. Hazards Earth Syst. Sci., 15, 135-146, doi:10.5194/nhess-15-135-2015, 2015.

Tavarnelli, E. and Prosser, G.: The complete Apennines orogenic cycle preserved in a transient single outcrop near San Fele, Lucania, Southern Italy, London, J. Geol. Soc., 160, 429-434, 2003.

Varnes, D. J.: Slope movements. Types and processes, in: Landslides: analysis and control, Spec. Rep. 176, Transp. Res. Board, Natl. Acad. Sci., Schuster \& Krizkereds, Washington, 11-13, 1978.

Zembo, I.: Stratigraphic architecture and quaternary evolution of the Val d'Agri intermontane basin (Southern Appennines, Italy), Sediment. Geol., 223, 206-234, 2010.

Zembo, I., Panzeri, L., Galli, A., Bersezio, R., Martini, M., and Sibilia, E.: Quaternary evolution of the intermontane Val d'Agri Basin, Southern Apennines, Quaternary Res., 72, 431-442, 2009. 